\title{
Cotton Leaf Curl Disease: Which Whitefly Is the Vector?
}

\author{
Li-Long Pan, Xi-Yun Cui, Qun-Fang Chen, Xiao-Wei Wang, and Shu-Sheng Liu ${ }^{\dagger}$
}

First, second, third, fourth, and fifth authors: Ministry of Agriculture Key Laboratory of Molecular Biology of Crop Pathogens and Insects, Institute of Insect Sciences, Zhejiang University, Hangzhou 310058, China. Accepted for publication 27 April 2018.

\begin{abstract}
Cotton leaf curl disease is one of the most significant constraints to the production of cotton. In the past decades our understanding of the begomoviruses (family Geminiviridae) causing the disease has improved, but little is known regarding transmission of these viruses by the different species of whiteflies in the Bemisia tabaci complex. We compared transmission efficiency of cotton leaf curl Multan virus (CLCuMuV), one of the major begomoviruses associated with cotton leaf curl disease, by four whitefly species, of which two are indigenous to Asia and two are invasive worldwide. Only the indigenous Asia II 1 species was able to transmit this virus with high efficiency. By quantifying the virus and

using immunoflorescence assays, we found that the differential transmission was associated with the varying efficiency of CLCuMuV to cross the midgut of various whitefly species. Further, we verified the role of coat protein in the whitefly transmission of CLCuMuV. Based on a phylogenetic analysis of the virus coat proteins, we found that most begomoviruses associated with cotton leaf curl disease might share similar whitefly transmission characteristics. These findings advance our understanding of the nature of cotton leaf curl disease and provide information for the development of control and preventive strategies against this disease.
\end{abstract}

Insects and plant viruses can seriously limit the production of crops. In recent decades begomoviruses (genus Begomovirus, family Gemiviridae), which are transmitted exclusively by whiteflies (Hemiptera: Aleyrodidae) of the Bemisia tabaci complex in nature, have emerged as serious threats to the production of many crops including cotton, tomato and cassava (Navas-Castillo et al. 2011). Diseases caused by begomoviruses include tomato yellow leaf curl, cassava mosaic and cotton leaf curl, all of which cause great losses to the production of economically important crops worldwide. Cotton leaf curl disease, first found in 1912 in Africa, is now considered to be the most significant constraint to cotton production in south Asia (Farooq et al. 2011; Sattar et al. 2013). In late 1980s, the first epidemic of cotton leaf curl disease occurred near the city of Multan, Pakistan, and rapidly spread to almost all cotton growing areas of the country and northwestern India (Sattar et al. 2013). Since then, each year this disease affects hundreds of thousands of hectares of cotton and causes hundreds of thousands bales ( 1 bale: 480 pounds) losses to cotton production (Farooq et al. 2011). Although resistant cotton varieties obtained through conventional breeding in late 1990s restored the production of cotton in Pakistan for a short period of time, the resistance was broken soon in 2001/2002 (Farooq et al. 2011; Mansoor et al. 2003).

To date 10 viruses from the genus Begomovirus, namely: cotton leaf curl Multan virus (CLCuMuV), cotton leaf curl Alabad virus (CLCuAlV), cotton leaf curl Bangalore virus (CLCuBaV), cotton leaf curl Kokhran virus (CLCuKoV), papaya leaf curl virus $(\mathrm{PaLCuV})$, tomato leaf curl Bangalore virus (ToLCBaV), cotton leaf curl Gezira virus (CLCuGeV), African cassava mosaic virus

†Corresponding author: S.-S. Liu; E-mail: shshliu@zju.edu.cn

Funding: Financial support for this study was provided by the National Natural Science Foundation of China grant 31390421.

First and second authors contributed equally to this work.

*The $e$-Xtra logo stands for "electronic extra" and indicates that four supplementary figures are published online.

(c) 2018 The American Phytopathological Society
(ACMV), tomato leaf curl New Delhi virus (ToLCNDV), okra enation leaf curl virus (OELCuV), and one virus from the genus Mastrevirus, chickpea chlorotic dwarf virus (CpCDV) have been identified to be associated with the leaf curl disease of cotton (Briddon 2003; Briddon et al. 2001, 2014; Hameed et al. 2014; Kirthi et al. 2004; Manzoor et al. 2014; Nawaz-ul-Rehman et al. 2012; Saleem et al. 2016; Tahir et al. 2011; Zaidi et al. 2016; Zhou et al. 1998; Zubair et al. 2017). In addition, a betasatellite associated with these viruses, cotton leaf curl Multan betasatellite (CLCuMuB), has been shown to play a key role in the etiology of cotton leaf curl disease (Briddon 2003). In 1990s, multiple viruses were identified in the diseased cotton plants, with CLCuMuV being dominant, whereas following the resistance breaking only a single begomovirus, the Burewala strain of cotton leaf curl Kokhran virus (CLCuKoV-Bur), was identified or found to be dominant (Briddon 2003; Briddon et al. 2001, 2014; Sattar et al. 2013; Zaidi et al. 2016; Zhou et al. 1998). Recently, multiple begomoviruses associated with cotton leaf curl disease in Pakistan in early 1990s were found to be back in cultivated cotton in Pakistan and India. CLCuMuV, which was extensively found in diseased cotton in 1990s, was recently found to be exclusive in diseased plants of regions with cotton leaf curl disease outbreak in 2015, indicating a displacement of CLCuKoV-Bur by CLCuMuV (Datta et al. 2017; Zubair et al. 2017).

Much less attention has been paid to another key player in the development of cotton leaf curl disease, the whitefly vectors of begomoviruses associated with the disease (Sattar et al. 2013). While field surveys of whitefly vectors have been conducted from time to time, fundamental questions remain to be answered regarding whitefly transmission of these begomoviruses, including the identification of whitefly species responsible for the transmission. Field surveys conducted in Punjab and Sindh provinces in Pakistan in 1995 to 1997 showed that at least two genetically distinct groups of viruses and three genetically distinct groups of whiteflies were present (Simón et al. 2003). Later, the whitefly species were identified as Asia II 1, Middle East-Asia Minor 1(MEAM1), and Asia 1 (Ahmed et al. 2011). Asia II 1 was found to be most abundant and closely associated with high incidence of cotton leaf curl disease (Ashfaq et al. 2014). Recent field surveys in Pakistan found 
that although the distribution of MEAM1 seemed to be expanding, Asia II 1 was still the dominant species (Masood et al. 2017). Gupta et al. (2010) conducted virus transmission experiments using field collected diseased plants and whiteflies without stating the species of virus and whitefly used. None of these studies unequivocally identified the whitefly species responsible for the epidemic of cotton leaf curl disease in the field.

Cotton is grown widely across the warmer parts of the world and in these regions the vector of cotton leaf curl disease, especially the two invasive whitefly species, Middle East-Asia Minor 1 (MEAM1, the former B biotype) and Mediterranean (MED, the former Q biotype) are widely distributed (De Barro et al. 2011). There is thus the concern that begomoviruses associated with this disease could spread from the presently limited geographical range to other cotton growing areas of the world, just like the way tomato yellow leaf curl virus (TYLCV) has been spreading (Lefeuvre et al. 2010; Sattar et al. 2013). This concern has become a reality in China where one of major begomoviruses associated with cotton leaf curl disease, CLCuMuV, was found on Hibiscus rosa-sinensis L. (Malvaceae) in Guangzhou, Guangdong in 2006 (Mao et al. 2008). This virus was subsequently reported to be causing leaf curl disease in cotton in Guangxi province (Cai et al. 2010). So far, no commercial cotton varieties or breeding lines have been found to be resistant to cotton leaf curl disease from Burewala, Pakistan (Akhtar et al. 2008; Sattar et al. 2013). Although no epidemic of cotton leaf curl disease has been reported in major cotton growing regions except the Indian subcontinent, the losses it has caused there, the worldwide distribution of $B$. tabaci and the lack of resistance in cotton indicate the likelihood of the disease to spread to other regions of cotton production and endanger cotton industry worldwide. Thus, urgent efforts are required to evaluate the threat, particularly transmission of the viruses by different whitefly species, in order to develop timely strategies for prevention and management of this disease in other regions.

In the present study, first, we compared the transmission of $\mathrm{CLCuMuV}$ by four whitefly species, of which two are indigenous to Asia and two are invasive worldwide. Second, we studied virus movement and distribution within the whitefly body after acquisition from the plant, trying to reveal the mechanisms underlying the differential transmission. Third, we verified the role of virus coat protein in whitefly transmission of CLCuMuV. Finally, we conducted a phylogenetic analysis of the coat protein of begomoviruses to gain an understanding of the transmission characteristics of begomoviruses associated with cotton leaf curl disease. Our findings provide the first detailed information regarding whitefly transmission of a begomovirus associated with cotton leaf curl disease and the underlying mechanism.

\section{MATERIALS AND METHODS}

Insects, plants, and virus. Four species of whitefly were used in the study, of which two are invasive worldwide including MEAM1 and MED, and two are indigenous to Asia including Asia 1 and Asia II 1. All four whitefly species were collected from the field between 2009 to 2012, and the mtCOI GenBank accession numbers for each of the species of whitefly are KM821540 for MEAM1, GQ371165 for MED, KC540757 for Asia 1, and DQ309077 for Asia II 1. One culture of each species was established and maintained on cotton plants (Gossypium hirsutum L. 'Zhemian 1793'). The purity of each whitefly culture was monitored every three generations using PCR-restriction fragment length polymorphism and mtCOI sequencing (Qin et al. 2013). All experiments with whitefly rearing were conducted in insect proof cages in artificial climate chambers at 26 to $28^{\circ} \mathrm{C}, 14 / 10 \mathrm{~h}$ light/dark, and 60 to $80 \%$ relative humidity.

For plants two cotton varieties (cultivar Zhemian 1793 and cultivar Guangxi 112-2) and one tobacco variety (Nicotiana tabacum L. 'NC89') were used. One cotton variety (Zhemian 1793) was used for whitefly rearing, whereas Guangxi 112-2 was used for virus transmission experiments as our preliminary experiments showed that Zhemian 1793 could not be infected by CLCuMuV through either whitefly transmission or agroinoculation, whereas Guangxi 112-2 could be infected. All plants were grown in insect proof greenhouses under natural lighting supplemented with artificial lighting for $14 \mathrm{~h}$ a day and controlled temperature at $25 \pm 3^{\circ} \mathrm{C}$.

Infectious clones of CLCuMuV isolate GD37 (GenBank accession number JN968573) and its associated betasatellite (JN968574) were provided by X. P. Zhou (Institute of Biotechnology, Zhejiang University) (Gu et al. 2015). Infectious clones of CLCuMuV were initially agroinoculated into two to three true leaf tobacco plants. Then whitefly transmission was used to obtain virus-infected tobacco plants for subsequent experiments. Prior to use in any experiment, the status of virus infection of each plant was determined by inspection for symptoms (Supplementary Fig. S1) and PCR. For PCR, the first fully expanded leaf of the plants was collected, and DNA extraction was performed using Plant Genomic DNA Kit (Tiangen, China), and then PCR were performed using primer $1\left(5^{\prime}\right.$ - TTCGGTGTATGCTTTCTGTC- $\left.3^{\prime}\right)$ and primer $2\left(5^{\prime}\right.$ ACCTGATAACGGTCCCTATG-3').

Virus acquisition and transmission. Whitefly adults, which had developed on cotton and emerged within 0 to 3 days, were collected and placed on virus-infected plants for various periods depending on the experiment to acquire the virus. For virus transmission experiments a given number of adults, as designated in the design, were collected after $48 \mathrm{~h}$ virus acquisition and caged on test plants to feed for another period of $48 \mathrm{~h}$. Leaf clip cages were used to enclose the whiteflies on test plants as described previously (Ruan et al. 2007). Immediately after the $48 \mathrm{~h}$ virus transmission, the whitefly adults were removed and kept for subsequent determination of infection status using PCR, and the test plants were sprayed with imidacloprid ( $20 \mathrm{mg} / \mathrm{liter})$ to kill all the whitefly eggs produced during the inoculation period. The test plants were then grown for about 4 weeks, and the virus infection status of the test plants was then determined by inspection for symptoms and PCR.

Comparison of CLCuMuV transmission among four species of whiteflies. Two transmission experiments were conducted using different species of test plants. Both experiment used CLCuMuV-infected tobacco to obtain viruliferous whiteflies for virus acquisition. In the first experiment, the four species of whiteflies (four treatments) were caged on cotton plants. Each treatment consists of 8 to 23 plants, and each plant was caged with 10 whiteflies for MED, Asia 1, and Asia II 1 and 30 for MEAM1 as preliminary experiments showed that 10 MEAM1 whiteflies did not result in successful transmission (data not shown). In the second experiment, the four species of whiteflies (four treatments) were caged on tobacco plants. Each treatment had three replicates with each consisting 11 to 12 plants, and each plant was caged with 10 whiteflies. Four weeks later, sampling of the test plants of each of the two experiments and subsequent DNA extraction and PCR detection were conducted as mentioned before. DNA samples from the second experiment were subjected to quantitative PCR analysis using AceQ qPCR SYBR Green Master Mix (Vazyme, China) and CFX96 Real-Time PCR Detection System (Bio-Rad) to quantify the virus. The primers for CLCuMuV quantification were primer 1 ( $5^{\prime}$ - ACACTTGTGCAGTCCCAGAG-3') and primer 2 (5'-CACTTCAACCGTCCATTCAC-3'), and primers for tobacco actin were primer 1 (5'-GTGTTAGCCACACTGTCCCA-3') and primer 2 (5'-TCAGTCAAGTCACGACCAGC-3').

Quantification of virus in whitefly whole body and honeydew. Whitefly adults were collected in groups of 15 at designated time points after the initiation of virus acquisition and lysed in lysis solution $(\mathrm{KCl}$ at $50 \mathrm{mmol} / \mathrm{liter}$, Tris at $10 \mathrm{mmol} / \mathrm{liter}$, $0.45 \%$ Tween $20,0.2 \%$ gelatin, $0.45 \%$ NP40, protease $\mathrm{K}$ at $60 \mathrm{mg} / \mathrm{ml}$ [pH 8.4]) followed by $1.5 \mathrm{~h}$ incubation at $65^{\circ} \mathrm{C}$ and $10 \mathrm{~min}$ at $100^{\circ} \mathrm{C}$ to obtain the template for the subsequent virus quantification. 
Quantitative PCR analysis was performed with primers for CLCuMuV as mentioned above and whitefly actin (primer 1: 5'-TCTTCCAGCCATCCTTCTTG-3' and primer 2: 5'-CGGTG ATTTCCTTCTGCATT-3') (Sinisterra et al. 2005).

Whitefly honeydew was collected using leaf clip cages. The leaves of virus-infected tobacco were laid flat and two leaf clip cages placed on the undersurface of each leaf, one for each of the two species for comparison. The bottom of the leaf clip cages was covered with aluminum foil so that the honeydew produced by whiteflies feeding on the leaves would fall onto the foil. At a designated interval of feeding time, the honeydew was collected with phosphate buffer saline (PBS) and viral DNA was extracted using PureLink Viral RNA/DNA Mini Kit (Invitrogen). Then the honeydew samples were subjected to real time PCR analysis. The copy number of virus in whitefly honeydew was calculated as normalized to a standard curve made by real time PCR reaction using the serial dilution of plasmid extracted from the infectious clone of CLCuMuV.

PCR detection and quantification of virus in dissected whitefly organs. For the PCR detection of CLCuMuV in whitefly whole body, individual adults $(n=22)$ were collected and lysed as described previously. Midguts and primary salivary glands $(n=17$ to 22) were dissected, washed twice with PBS, and then lysis solution (as above) was added. For the collection of whitefly haemolymph ( $n=20$ to 22 ), individual whiteflies were placed into PBS on glass slides, the abdomen was cut to release the contents, the intact midgut was removed, and the remaining liquid was collected using fine pipettes and lysis buffer was added. The DNA extraction of these samples was performed following the methods of DNA extraction of whitefly whole body. PCR detection of viral DNA in these samples was conducted as mentioned before, and the quantification of CLCuMuV was conducted with the same method as that for whitefly whole body.

Immunofluorescence detection of viruses in whitefly midguts and primary salivary glands. The immunofluorescence detection of viruses was performed using the methods described by Wei et al. (2014) with minor modifications. For virus detection using immunofluorescences, anti-TYLCV monoclonal antibodies (provided by X. P. Zhou, Institute of Biotechnology, Zhejiang University) were used. At each time point designated, midguts and primary salivary glands from whiteflies were dissected in PBS and fixed in $4 \%$ paraformaldehyde (MultiSciences Biotech., China) for $1 \mathrm{~h}$ at room temperature, permeabilized with $0.2 \%$ Triton X-100 for $30 \mathrm{~min}$, and then blocked with $1 \%$ BSA dissolved in TBS-Tween 20 (TBST) for $1 \mathrm{~h}$ at room temperature. Organs were then incubated with anti-TYLCV monoclonal antibodies at a 1:400 dilution overnight at $4{ }^{\circ} \mathrm{C}$ and the next day incubated using 549-conjugated secondary antibodies (1:400) (Earthox, China) for $2 \mathrm{~h}$ at room temperature. The viral signal was examined under a Zeiss LSM710 confocal microscope (Zeiss, Germany).

Construction of mutant viruses and infection of plants. To explore whether viral coat protein determined the ability of begomoviruses to cross the whitefly midgut barrier, we constructed two mutant viruses based on TYLCV isolate $\mathrm{SH} 2$ and CLCuMuV isolate GD37. The genes that encode coat protein (V1) were partially exchanged as shown in Supplementary Fig. S2 and construction of infectious clones of mutant TYLCV (mTYLCV) and CLCuMuV (mCLCuMuV) were conducted as previously described (Cui et al. 2004; Wei et al. 2014). Briefly, the full length genome of the two viruses were cloned into pGEM-T vector (Promega, USA), then the full length genome of mutant mTYLCV and mCLCuMuV were obtained using ClonExpress II One Step Cloning Kit (Vazyme, China). Infectious clones of mTYLCV and mCLCuMuV were constructed as described (Gu et al. 2015; Zhang et al. 2009).

Phylogenetic analysis of the coat protein amino acid sequences of begomoviruses. The amino acid sequences of the coat protein of the type isolate of all begomovirus species deposited in GenBank (Brown et al. 2015) were downloaded. In total, we downloaded and phylogenetically analyzed 304 coat protein amino acid sequences and that of the curtovirus Beet curly top virus was used as an outgroup. The phylogenetic analysis was conducted with MEGA 5.0 (Tamura et al. 2011).

Statistical analysis. For all the data obtained, normal distribution test was performed prior to analysis. For analysis of virus transmission efficiency all percentage data were arcsine square root transformed, and one-way analysis of variance (ANOVA) along with Fisher's least significant difference (LSD) tests were used. For the comparison of quantity of virus in plants, whitefly whole body and organs, all real time data were calculated using $2^{-\triangle \mathrm{Ct}}$ as normalized to actin. For comparison of relative virus quantity in test plants, Kruskal-Wallis test was used. For the analysis of relative quantity of virus in whitefly whole body between the two whitefly species at each time point, Student's independent $t$ test was used, whereas for analysis of quantity of virus in midgut, haemolymph, and primary salivary glands, nonparametric $t$ test (Mann-Whitney) was used. All data are presented as the mean \pm standard errors of mean (mean \pm SEM). The differences between treatments were considered significant when $P<0.05$. All statistical analysis was conducted using SPSS 20.0 Statistics and EXCEL.

\section{RESULTS}

CLCuMuV transmission efficiency by four whitefly species. Four species of the B. tabaci complex, MEAM1, MED, Asia 1, and Asia II 1, were compared for their efficiency of CLCuMuV transmission. In the first experiment, when cotton plants were used as test plants, the transmission efficiency of CLCuMuV by Asia II 1 were 52.2 and $43.5 \%$ based on PCR detection of viral DNA and symptom inspection, respectively, whereas for MEAM1, MED, and Asia 1, the transmission rate was 0 as shown by both methods (Table 1). The observed symptoms included downward curling of the leaf margins, vein swelling, vein darkening, and enations as previously reported (Fig. 1) (Briddon et al. 2001). In the second experiment using tobacco as test plants, the average transmission efficiencies of CLCuMuV by MEAM1, MED, Asia 1, and Asia II 1 were 19.7, 25.8, 19.9, and 79.3\% based on PCR detection of viral DNA in test plants $\left(\mathrm{F}_{3,8}=49.01, P<\right.$ 0.001) (Fig. 2A). Likewise, the percentages of plants with virus infection symptom differed between the four whitefly species with a similar pattern; the transmission efficiencies of CLCuMuV by MEAM1, MED, Asia 1, and Asia II 1 were $0,8.3,0$, and $64.1 \%$ $\left(\mathrm{F}_{3,8}=26.62, P<0.001\right)$ (Fig. 2B). Further quantitative PCR showed that the quantity of virus in test plants inoculated by Asia II 1 was the

TABLE 1. Transmission efficiency of cotton leaf curl Multan virus to cotton by four species of the Bemisia tabaci complex ${ }^{\mathrm{a}}$

\begin{tabular}{lcccc}
\hline Whitefly species & Number of whiteflies per plant & Number of plants tested & $\begin{array}{c}\text { Percent transmission as } \\
\text { indicated by PCR }\end{array}$ & $\begin{array}{c}\text { Percent transmission as } \\
\text { indicated by symptom }\end{array}$ \\
\hline MEAM1 & 30 & 12 & $0 \%$ & $0 \%$ \\
MED & 10 & 8 & $0 \%$ & $0 \%$ \\
Asia 1 & 10 & 10 & $0 \%$ & $0 \%$ \\
Asia II 1 & 10 & 23 & $52.2 \%$ & $43.5 \%$ \\
\hline
\end{tabular}

${ }^{a}$ The number of whiteflies per test plant and replicates was listed in the table. Data were presented as the percentage of PCR-positive test plants and percentage of test plants that showed typical symptoms in all plants used. 
highest, followed by MED and Asia 1, and the lowest by MEAM1 (Kruskal-Wallis tests, $\chi^{2}=53.63, P<0.001$; Fig. 2C).

CLCuMuV acquisition capacity of MEAM1 and Asia II 1. Asia II 1 has a much higher CLCuMuV transmission capacity than MEAM1 (Fig. 2 and Table 1), so we compared the relative quantity of virus in the two whitefly species, and found that at each time point we examined $(6,12,24,48,96$, and $168 \mathrm{~h})$, the quantity of virus in Asia II 1 was significantly higher than that in MEAM1 $(t=8.96$, $3.82,5.87,4.79,10.83$, and 17.23 for $6,12,24,48,96$, and $168 \mathrm{~h}, P<$ 0.05 in all cases) (Fig. 3A). In the case of Asia II 1, as the feeding time increases, there was an obvious increase of virus quantity, while in MEAM1, the virus quantity stayed at low levels (Fig. 3A). The relative quantity of virus in the honeydew excreted by MEAM1 was significantly higher than Asia II 1 at three time points tested, i.e., 24,48 , and $168 \mathrm{~h}$ (Mann-Whitney test, $\mathrm{U}<1, P<0.001$ for $24 \mathrm{~h}$; $\mathrm{U}=2, P=0.002$ for $48 \mathrm{~h}$; $\mathrm{U}=8, P=0.012$ for $168 \mathrm{~h}$ ) (Fig. 3B, C, and D).

Quantity of CLCuMuV in organs of MEAM1 and Asia II 1. Using PCR to detect the viral DNA in whitefly organs, after $24 \mathrm{~h}$ virus acquisition, CLCuMuV was detected in most samples of whole body and midgut from MEAM1 and Asia II 1, whereas it was detected only in $33 \%$ of the haemolymph samples and $47 \%$ of
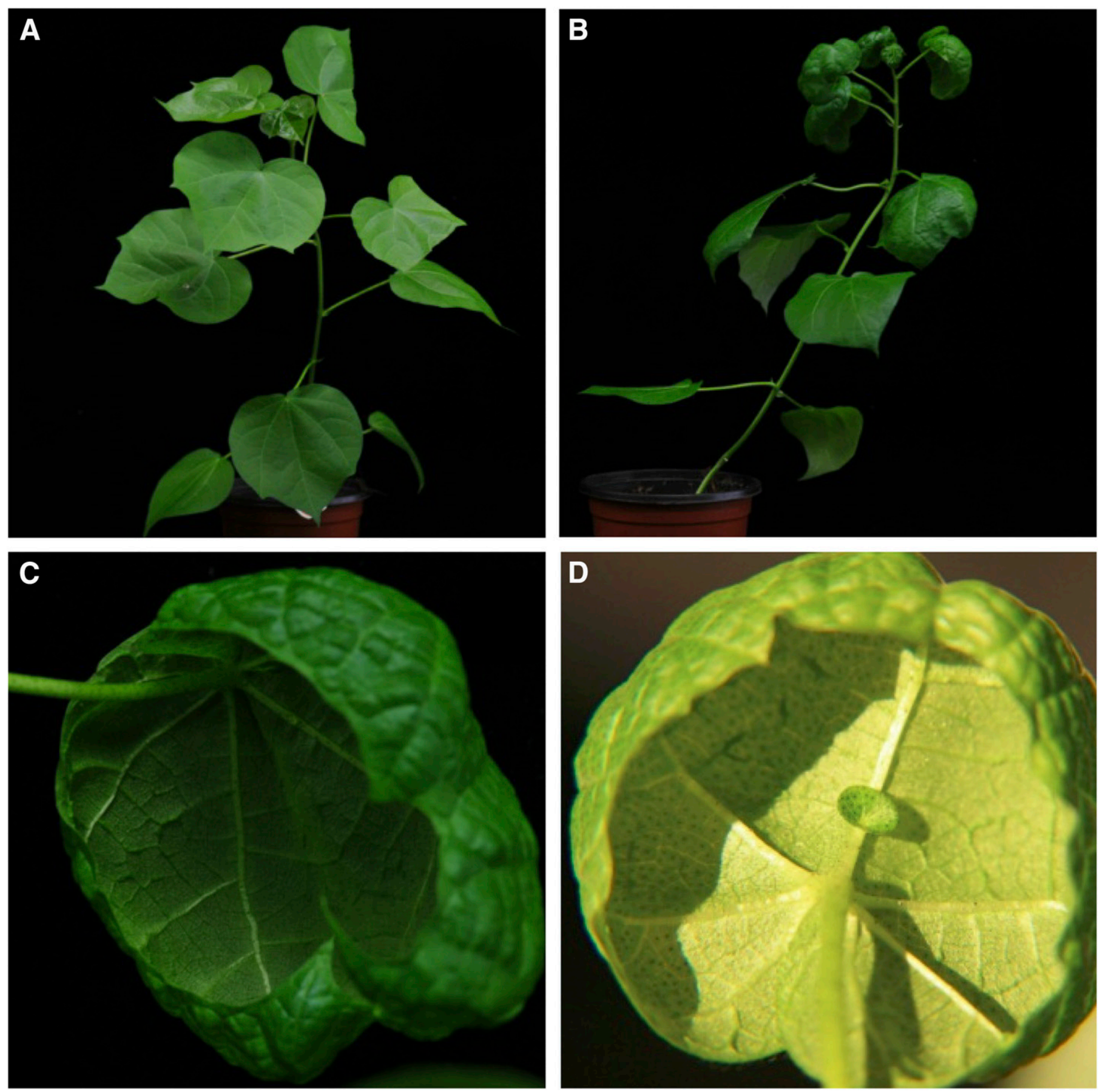

Fig. 1. Uninfected cotton plants and cotton leaf curl Multan virus (CLCuMuV)-infected cotton plants. Compared with uninfected plants, CLCuMuV-infected cotton plants showed downward curling of the leaf margins, vein swelling, vein darkening, and enations. A and B, The whole view of an uninfected and a CLCuMuVinfected cotton plant. Also shown are enlarged views of a cotton leaf showing downward curling of the leaf margins, vein swelling, $\mathbf{C}$, vein darkening, and $\mathbf{D}$, enation. 
primary salivary gland samples from Asia II 1 and none were detected in both types of samples from MEAM1 (Table 2). After $48 \mathrm{~h}$ virus acquisition, CLCuMuV was detected in more haemolymph and primary salivary gland samples from Asia II 1(77 and 65\%, respectively), whereas there was none in both types of samples from MEAM1 (Table 2). We also analyzed the quantity of CLCuMuV in midgut, haemolymph, and primary salivary gland, after 24 and $48 \mathrm{~h}$ virus acquisition by qPCR. The relative quantity of virus in midgut, haemolymph, and primary salivary glands dissected from Asiall1 whiteflies was significantly higher than that of MEAM1 whiteflies

A

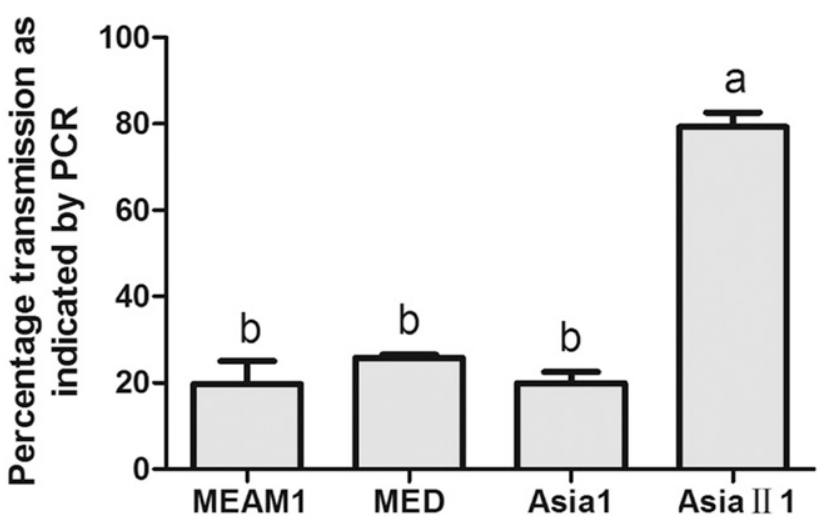

B
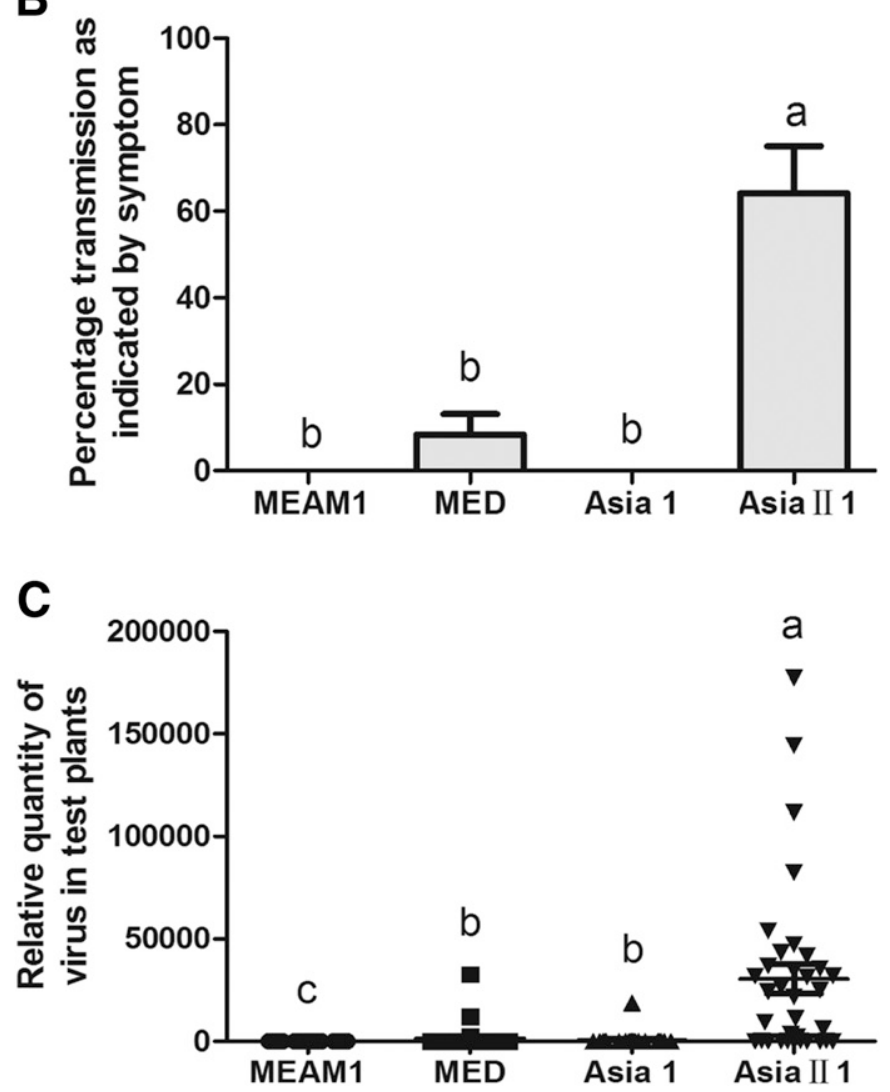

Fig. 2. Transmission efficiency of cotton leaf curl Multan virus to tobacco by four species of the Bemisia tabaci complex. The number of whiteflies per test plant was 10, and in each experiment, three replicates were conducted with each containing 10 to 12 test plants. Data presented as the mean \pm standard error of the mean (SEM) of $\mathbf{A}$, the percentage of PCR-positive test plants and $\mathbf{B}$, percentage of test plants that showed typical symptoms in all plants used. $\mathbf{C}$, Data are presented as the mean \pm SEM of the relative quantity of virus in all test plants used. Different letters above the bars indicates a significant difference (one-way analysis of variance, $P<0.05$ for A and B; Kruskal-Wallis test, $P<0.05$ for $\mathrm{C}$ ).
(Mann-Whitney test, $\mathrm{U}=6,79,102$ for midgut, haemolymph, and primary salivary gland at $24 \mathrm{~h}$, and $\mathrm{U}=10,87,3$ for midgut, haemolymph, and primary salivary gland at $48 \mathrm{~h}, P<0.05$ in all cases) (24 h: Fig. 4A, B, and C; 48 h: Fig. 4D, E, and F).

CLCuMuV signals in the midguts and primary salivary glands of MEAM1 and AsiaII1. After the adults of MEAM1 and Asia II 1 were given a feeding time of 6, 12, 24, 48, 96, and $168 \mathrm{~h}$ for virus acquisition, CLCuMuV signals were detected in the midguts and primary salivary glands using immunofluorescence. For midguts, in MEAM1, no viral specific signal was found for the entire period (Fig. 5A, upper panel), while in Asia II 1, obvious virus signal was evident after $48 \mathrm{~h}$ feeding, and the signal increased with the increase of feeding time showing an enrichment of virus signal in the filter chamber (Fig. 5A, lower panel). For primary salivary glands, no viral specific signal was found at all time points tested in MEAM1 (Fig. 5B, upper panel), while in Asia II 1 virus signals were evident after $96 \mathrm{~h}$ feeding, and the signal increased when the feeding time was increased to $168 \mathrm{~h}$, with all signals specifically located in the central secretory region along the ducts of the primary salivary glands (Fig. 5B, lower panel).

CLCuMuV acquisition capacity, quantity of virus in organs of MED and Asia II 1. The quantity of virus in whole body in Asia II 1 was higher than that of MED at three time points tested, significantly so at $96 \mathrm{~h}$ and $168 \mathrm{~h}(t=2.51, P=0.170$ for $48 \mathrm{~h} ; t=$ 13.31, $P=0.001$ for $96 \mathrm{~h} ; t=15.21, P<0.001$ for $168 \mathrm{~h}$ ) (Fig. 6A). The quantity of virus in honeydew at two time points tested ( 24 and $48 \mathrm{~h}$ ) was significantly lower in Asia II 1 whiteflies than that of MED (Mann-Whitney test, $\mathrm{U}=10, P=0.021$ for $24 \mathrm{~h}$ and $\mathrm{U}=3, P=$ 0.001 for $48 \mathrm{~h}$ ) (Fig. 6B and C). Further, the quantity of virus in all the three organs from Asia II 1 was significantly higher than that of MED after $48 \mathrm{~h}$ virus acquisition (Mann-Whitney test, $\mathrm{U}=31, P=$ 0.032 for midgut; $\mathrm{U}=9, P<0.001$ for haemolymph; $\mathrm{U}<1, P<$ 0.001 for primary salivary gland) (Fig. 6D, E, and F). Using immunofluorescence at three time points $(48,96$, and $168 \mathrm{~h})$, virus signal was detected in the midgut of both whitefly species, and more signal was found in the midgut of Asia II 1 at all three time points tested (Fig. 6G). For primary salivary glands, in Asia II 1 the virus signal was found when the feeding time was set at $96 \mathrm{~h}$ and became stronger at $168 \mathrm{~h}$. No virus signal was found in primary salivary glands dissected from MED at all time points tested (Fig. 6H).

Mutant viruses in midguts and primary salivary glands of MEAM1. Previous studies have shown that TYLCV is able to cross the midgut of MEAM1 readily and the virus was transmitted by MEAM1 with high efficiency (Wei et al. 2014). To investigate whether the coat protein of $\mathrm{CLCuMuV}$ determined its efficiency to cross the whitefly midguts, we exchanged the coat protein of CLCuMuV and TYLCV and generated two mutant viruses. After a $48 \mathrm{~h}$ virus acquisition, the signal of mutant virus (mCLCuMuV) was readily detected in both the midgut and primary salivary gland of MEAM1, while no signals of CLCuMuV could be detected in either of the organs (Fig. 7A and B). When the coat protein gene of TYLCV was replaced by that of CLCuMuV, the signal of mutant virus (mTYLCV) could not be detected in both the midgut and primary salivary gland of MEAM1 after a $48 \mathrm{~h}$ virus acquisition, while the virus signals of TYLCV were readily detected (Fig. 7C and D). Even after a longer feeding time of $168 \mathrm{~h}$ by MEAM1 on mTYLCV-infected tobacco, no virus signals were detected in either midgut or primary salivary gland (data did not show).

Phylogenetic analysis of coat proteins of begomoviruses. In the phylogenetic trees constructed for coat proteins of begomoviruses based on neighbor-joining (Supplementary Fig. $\mathrm{S} 3$ ), we found that in the branch where CLCuMuV was located, there were a further six begomoviruses associated with cotton leaf curl disease, CLCuAlV, CLCuBaV, CLCuKoV, PaLCuV, TOLCNDV, and ToLCBaV (Fig. 8). In the phylogenetic trees constructed for coat proteins of begomoviruses based on maximum-likelihood and 
minimum-evolution, these seven begomoviruses were also found to be within the same branch (Supplementary Fig. S4).

\section{DISCUSSION}

In the present study, we first compared the virus transmission efficiency of CLCuMuV by four species of whitefly and found that Asia II 1 transmitted this virus with much higher efficiency than the other whiteflies tested. The higher transmission capacity of Asia II 1 compared with that of MEAM1 is consistent with a previous report (Chen et al. 2016). The low CLCuMuV transmission capacity of both MEAM1 and MED whiteflies suggests that in a region where only these two whitefly species were present, epidemics of $\mathrm{CLCuMuV}$ are unlikely to emerge due to the lack of an efficient vector. Indeed, in China, CLCuMuV was firstly found in 2006, and later although this virus was found in multiple provinces in China, no epidemics of this virus on cotton has been reported so far probably due to the fact that in northern and northwestern China where cotton is widely grown, only MEAM1 and MED whiteflies are found (Hu et al. 2011). Besides, in China, so far CLCuMuV has only been found in a few plants, mainly the ornamental Hibiscus rosa-sinensis. As this plant is propagated by cuttings, it is highly likely that CLCuMuV has been spreading along with the infected plant material. However, our study tested the transmission of CLCuMuV by only two indigenous whitefly species from Asia, more studies, which should include other indigenous whitefly species from Asia, Africa, and America, are warranted to evaluate the potential threat of this virus in other continents.

To explore the mechanism underlying the differential transmission of CLCuMuV by different species of whitefly, we traced
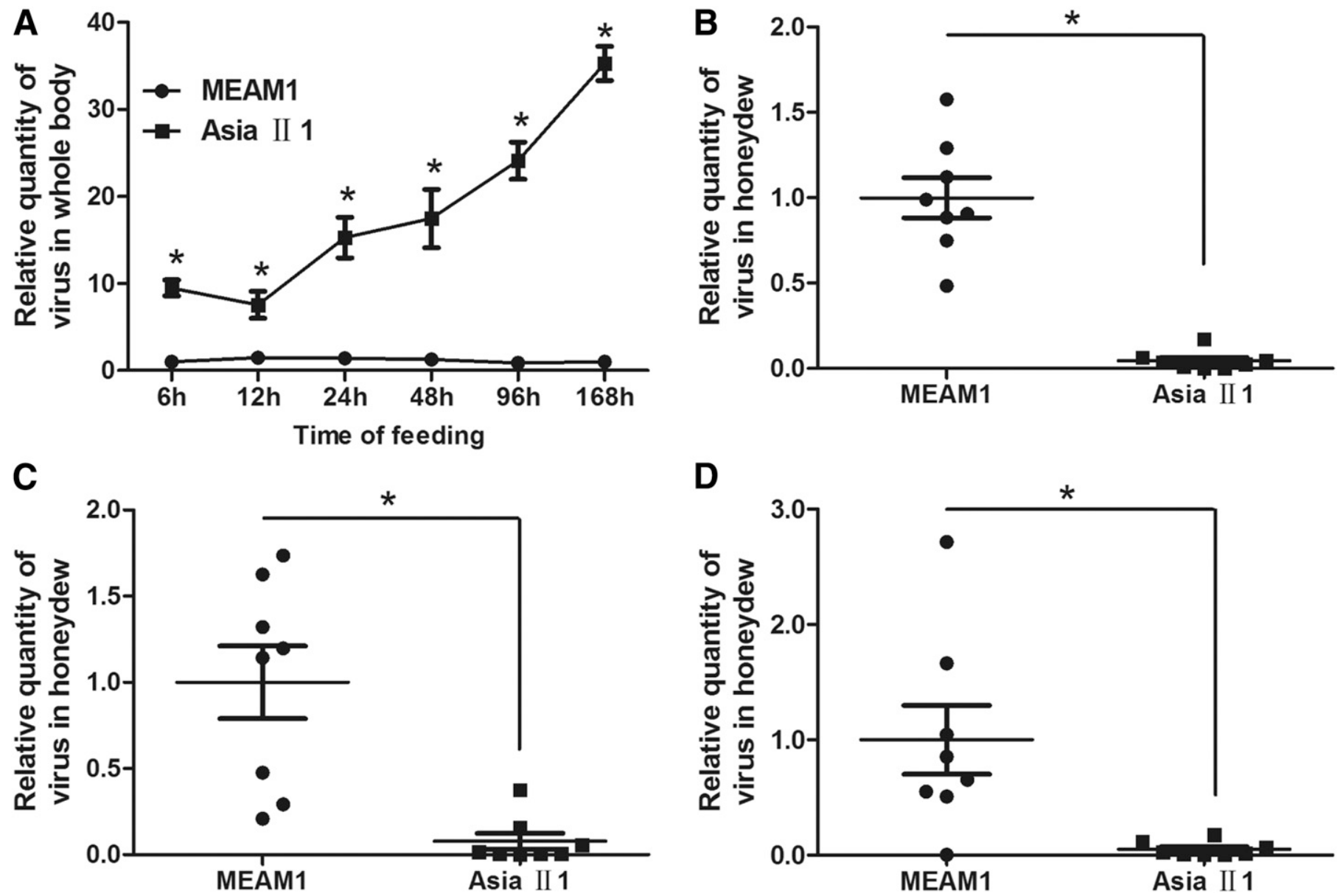

Fig. 3. Quantity of cotton leaf curl Multan virus (CLCuMuV) in the whole body and honeydew of MEAM1 and Asia II 1 whiteflies. A, For the analysis of quantity of virus in whitefly whole body, whiteflies were allowed to acquire CLCuMuV continuously, and at each time point indicated, three to four samples were collected for each of the two whitefly species. For analysis of quantity of virus in honeydew, the honeydew of whiteflies was collected after they had fed on CLCuMuVinfected plants for B, $24 \mathrm{~h}, \mathbf{C}, 48 \mathrm{~h}$, and D, $168 \mathrm{~h}$, respectively, and for each combination of time points and whitefly species, eight replicates were conducted. Data are presented as the mean \pm SEM of relative quantity of virus and $*$ indicates a significant difference (independent $t$ test, $P<0.05$ for A; Mann-Whitney $U$ test, $P<$ 0.05 for $\mathrm{B}, \mathrm{C}$, and $\mathrm{D})$.

TABLE 2. PCR detection of cotton leaf curl Multan virus (CLCuMuV) in the midgut, haemolymph, and primary salivary gland of MEAM1 and Asia II 1 whiteflies $^{\mathrm{a}}$

\begin{tabular}{lccccc}
\hline Time of feeding & Whitefly species & Whole body & Midgut & Haemolymph & Primary salivary gland \\
\hline $24 \mathrm{~h}$ & MEAM1 & $100.0 \%(22 / 22)$ & $75.0 \%(15 / 20)$ & $0 \%(0 / 20)$ & $0 \%(0 / 17)$ \\
& Asia II 1 & $95.5 \%(21 / 22)$ & $80.0 \%(16 / 20)$ & $33.3 \%(7 / 21)$ & $47.1 \%(8 / 17)$ \\
$48 \mathrm{~h}$ & MEAM1 & $90.9 \%(20 / 22)$ & $86.4 \%(19 / 22)$ & $0 \%(0 / 22)$ & $0 \%(0 / 20)$ \\
& Asia II 1 & $86.4 \%(19 / 22)$ & $90.9 \%(20 / 22)$ & $77.3 \%(17 / 22)$ & $65.0 \%(13 / 20)$ \\
\hline
\end{tabular}

\footnotetext{
${ }^{a}$ Whiteflies were allowed to acquire CLCuMuV for 24 and $48 \mathrm{~h}$, respectively, and then DNA samples of midgut, haemolymph, and primary salivary gland were prepared and subjected to PCR detection of CLCuMuV. The number of samples tested was listed in the table. Data were presented as the percentage of PCRpositive samples, followed by the number of PCR-positive samples and all samples tested.
} 

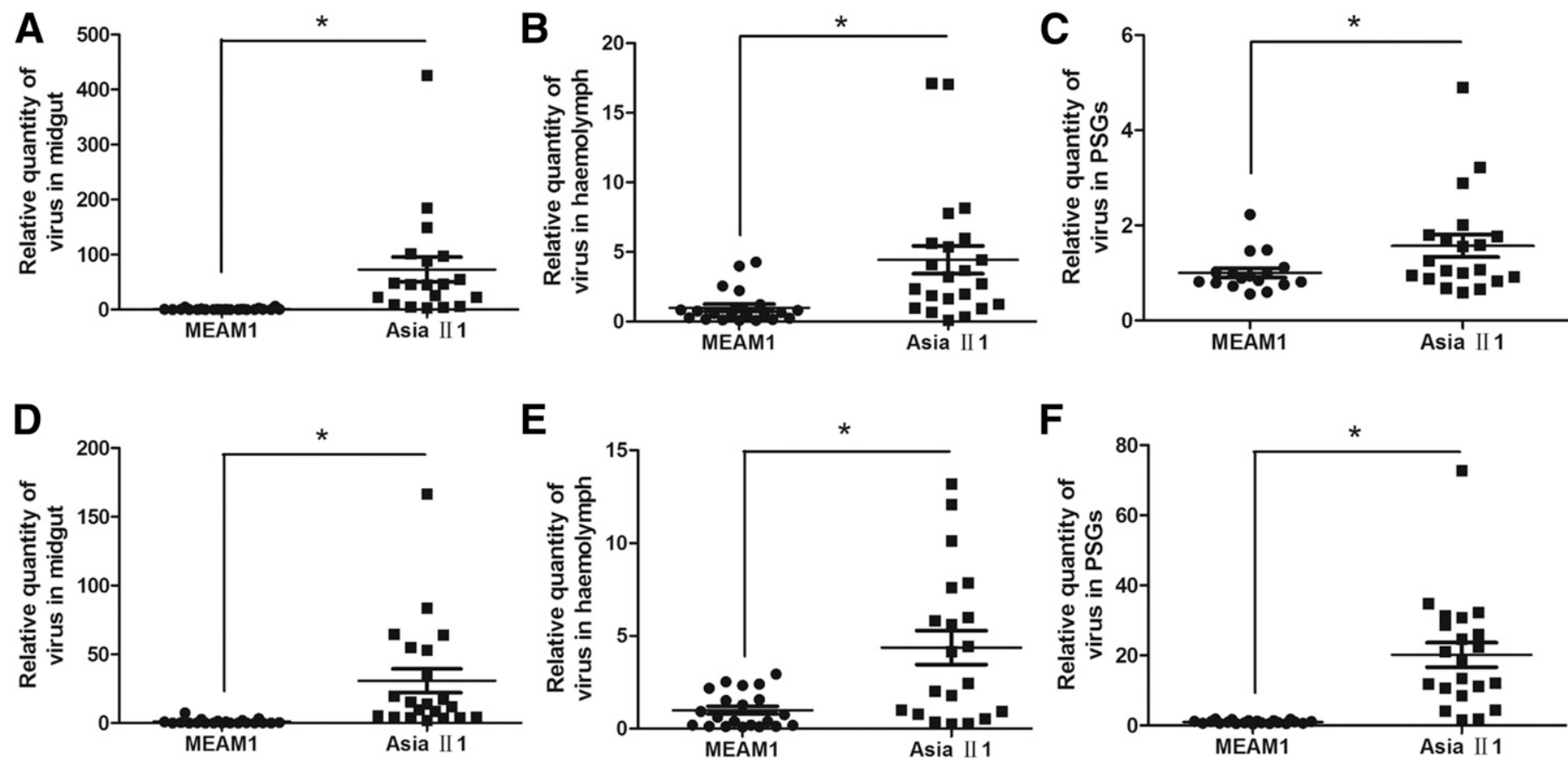

Fig. 4. Quantity of virus in the midgut, haemolymph, and primary salivary glands (PSGs) of MEAM1 and Asia II 1 whiteflies. Whiteflies were allowed to acquire cotton leaf curl Multan virus for $\mathbf{A}, \mathbf{B}$, and $\mathbf{C}, 24 \mathrm{~h}$ and $\mathbf{D}, \mathbf{E}$, and F, $48 \mathrm{~h}$, respectively, and then DNA samples of midgut, haemolymph, and primary salivary gland were prepared and subjected to real-time PCR. The number of samples tested was 17 to 22 . Data are presented as the mean \pm SEM of relative quantity of virus and * indicates a significant difference (Mann-Whitney $U$ test, $P<0.05$ ).

A

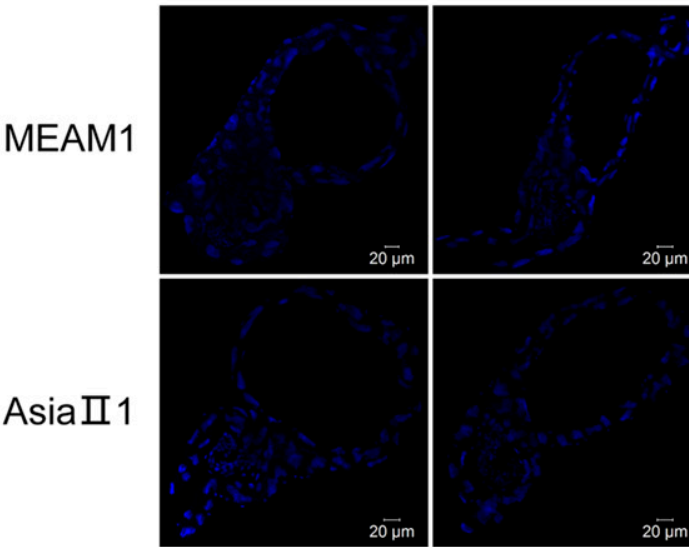

$24 \mathrm{~h}$

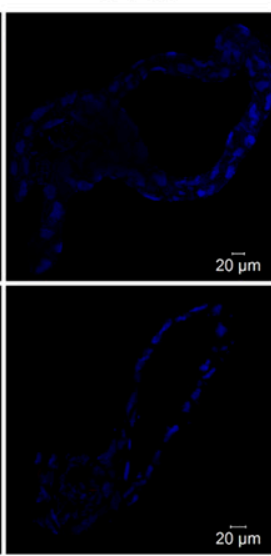

$48 \mathrm{~h}$

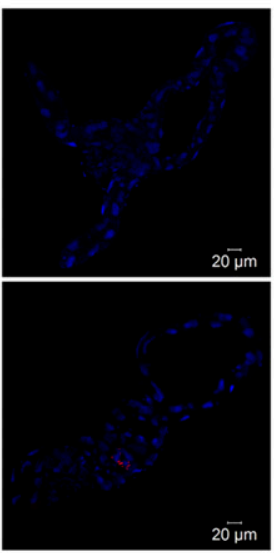

$96 \mathrm{~h}$

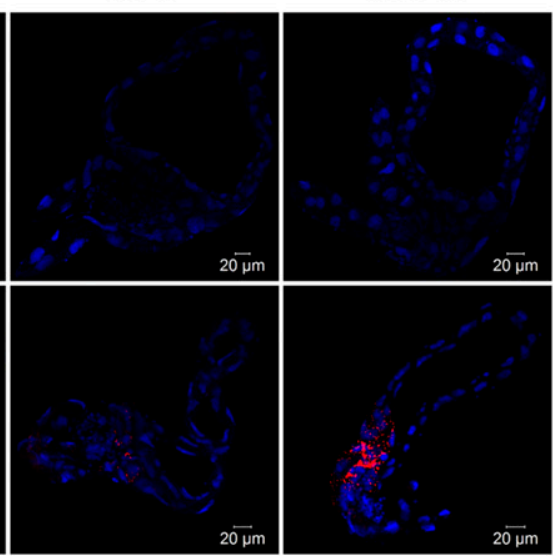

B

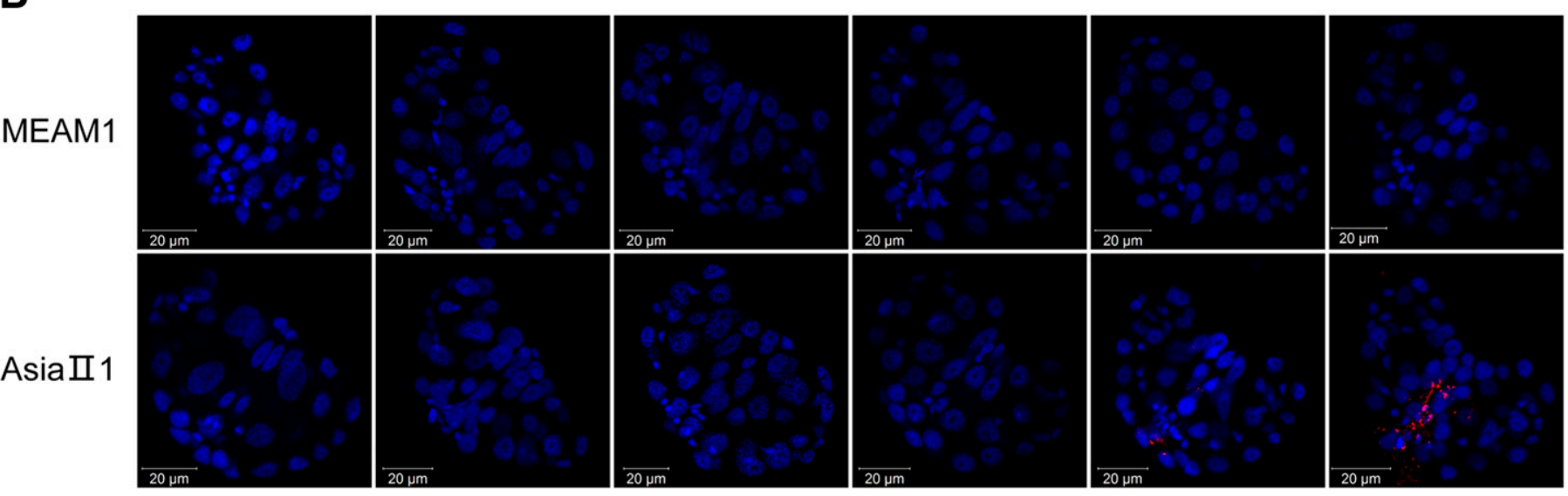

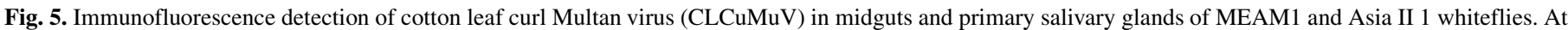

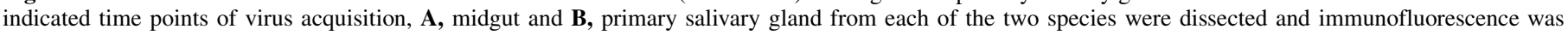

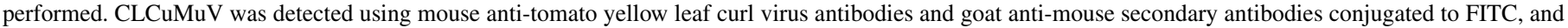
nuclei were stained with DAPI. Images showing the typical virus signal are presented. 
viral DNA in whitefly organs involved in transmission and found that in both MEAM1 and MED, the weak capacity of CLCuMuV to cross the midgut might be the reason for low transmission (Figs. 4, 5, and 6; Table 2). As in successful transmission begomoviruses follow a path of mouthparts to midgut, haemolymph, and then primary salivary gland once orally acquired, the midgut represents the first and one of the most important barriers the virus needs to cross (Ghanim et al. 2001; Rosen et al. 2015). Indeed, when a begomovirus fails to cross the midgut of a certain insect species, no transmission will be achieved, such as in the case of TYLCV with Trialeurodes vaporariorum Westwood (Czosnek et al. 2002). So far clathrin mediated endocytosis, early endosomes and the tubular endosomal network have been illustrated to be specifically involved in the transport of begomoviruses across the midgut of its whitefly vector (Pan et al. 2017; Xia et al. 2018). In our case, CLCuMuV was found to be able to cross the midgut of MEAM1 and MED
A

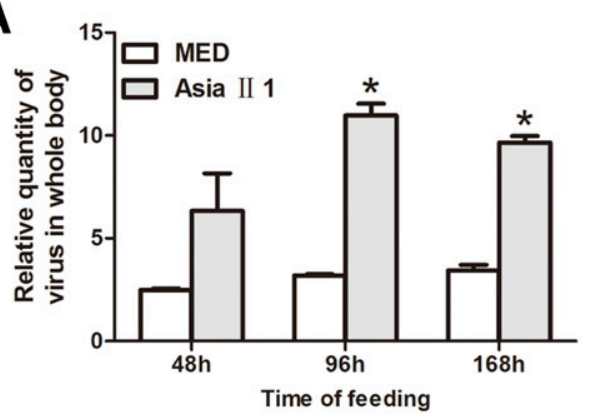

D

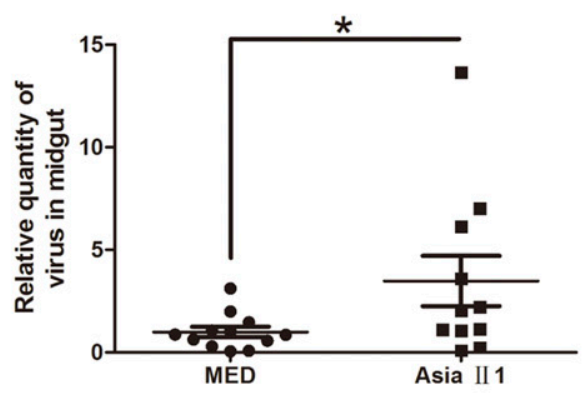

G

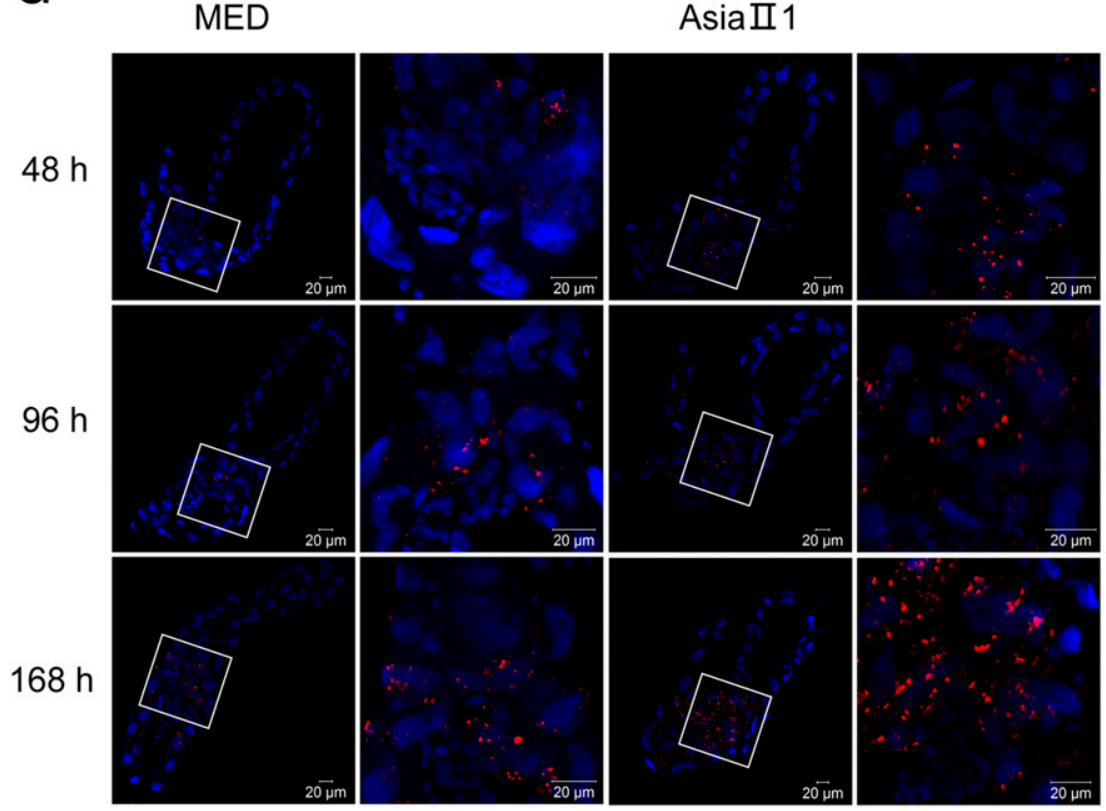

$\mathbf{E}$
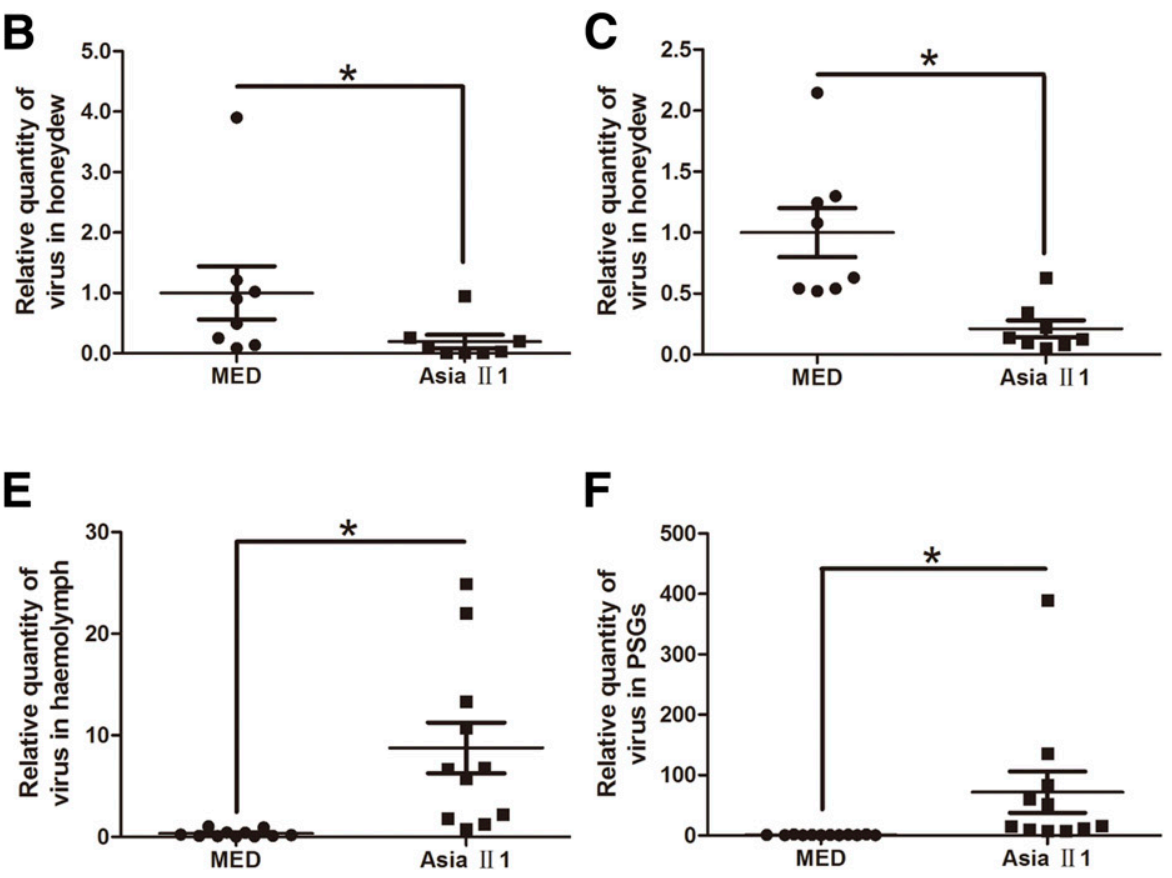

H

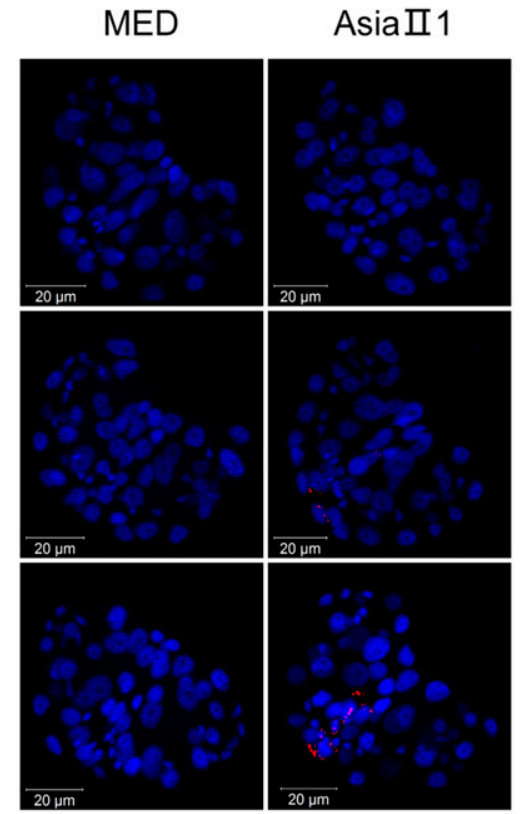

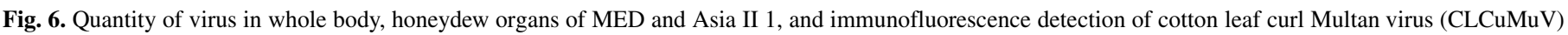

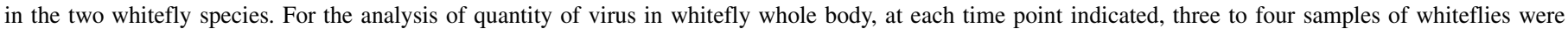

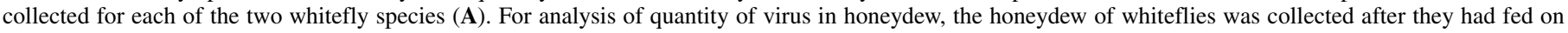

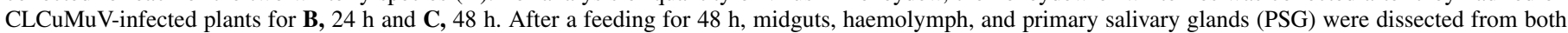

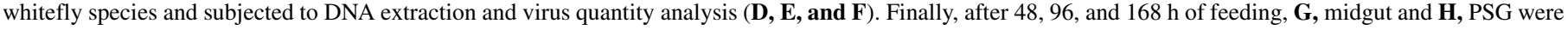

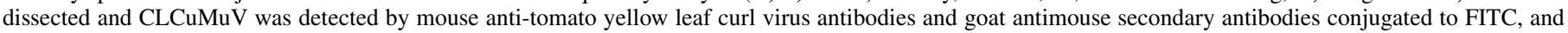

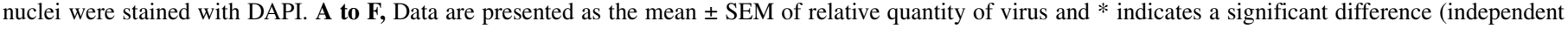
$t$ test, $P<0.05$ for A; Mann-Whitney $U$ test, $P<0.05$ for B, C, D, E, and F). 
whiteflies, but with much lower efficiency as compared with that of Asia II 1. It will be interesting to explore the underlying mechanisms, and a detailed exploration of this difference between whitefly species will surely provide valuable information to advance our understanding of whitefly transmission of begomoviruses.

Based on our phylogenetic analysis, the coat proteins of most cotton leaf curl disease related begomoviruses (7 out of 10) shared high identity compared with other begomoviruses and were located in the same branch (Fig. 8). Notably, tobacco curly shoot virus (TbCSV), which is located in the same branch with most of the cotton leaf curl disease related begomoviruses, has been shown to be transmitted by Asia II 1 with high efficiency and inefficiently by MEAM1, and this virus was also found to possess a stronger capacity to cross the midgut of Asia II 1 than MEAM1 (L. L. Pan, Q. F. Chen, T. Guo, X. R. Wang, P. Li, X. W. Wang, and S. S. Liu,
A

\section{CLCUMV}

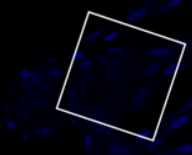

mCLCUMV

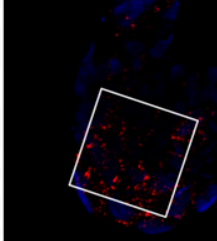

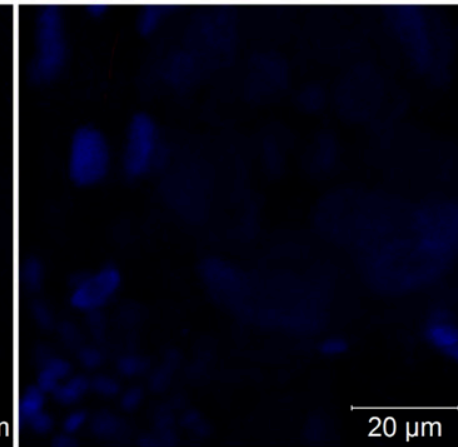

$20 \stackrel{\longmapsto}{\mu m}$

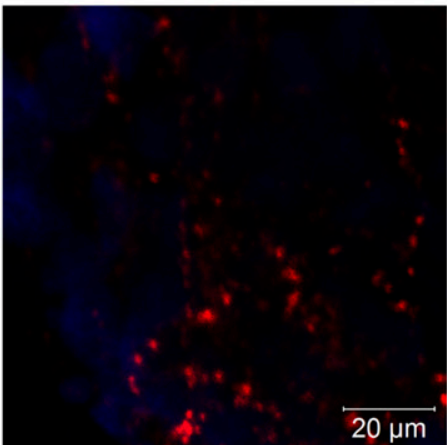

C

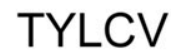

mTYLCV
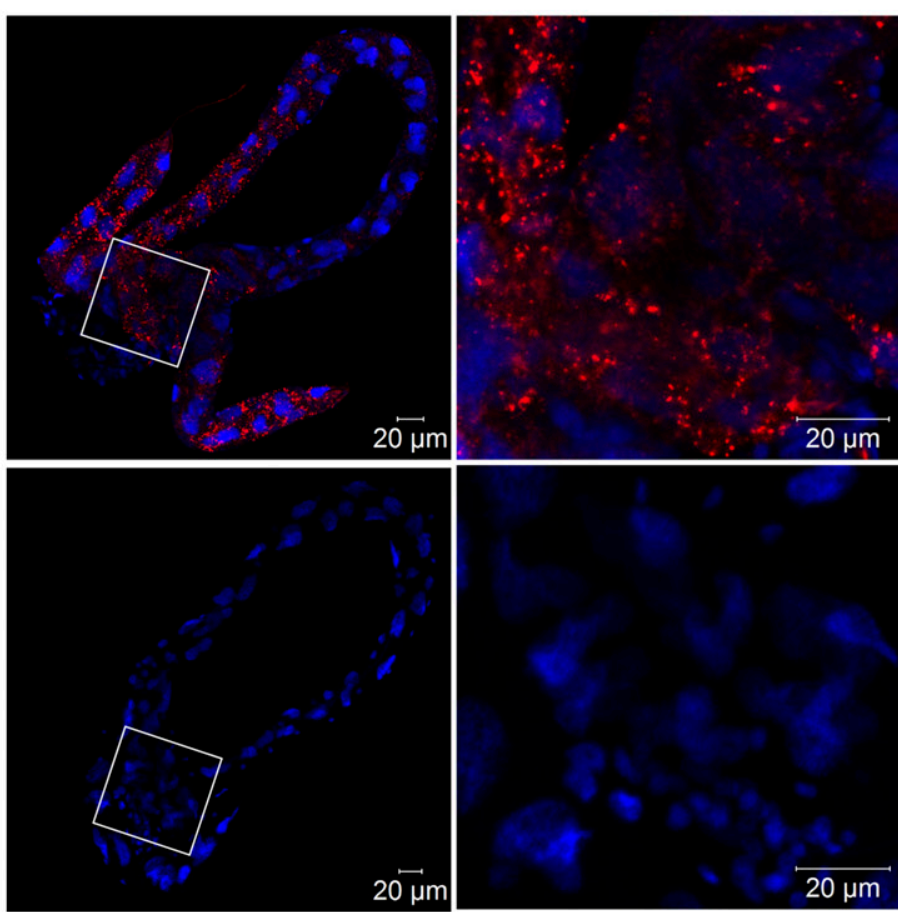

B
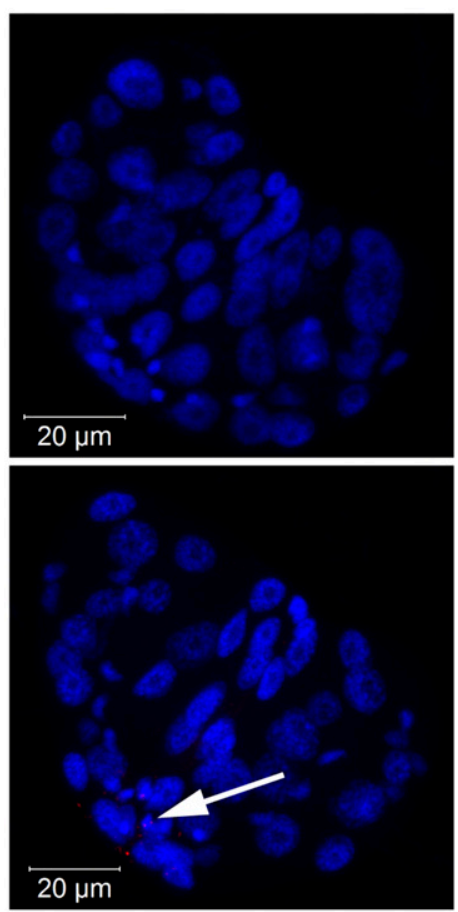

D
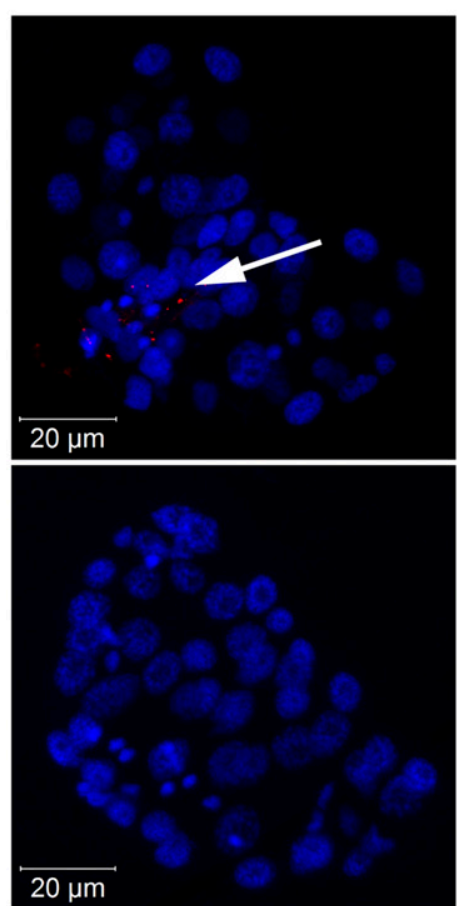

Fig. 7. Immunofluorescence detection of cotton leaf curl Multan virus (CLCuMuV), mutant CLCuMuV (mCLCuMuV), tomato yellow leaf curl virus (TYLCV), and mutant TYLCV (mTYLCV) in midgut and primary salivary gland of MEAM1 whiteflies. Post $48 \mathrm{~h}$ virus acquisition, $\mathbf{A}$ and $\mathbf{C}$, midguts and $\mathbf{B}$ and $\mathbf{D}$, primary salivary glands were dissected and CLCuMuV and mCLCuMuV were detected by mouse anti-TYLCV antibodies and goat anti-mouse secondary antibodies conjugated to FITC, and nuclei were stained with DAPI. Arrowheads indicate the virus signals in primary salivary gland in B and D. 
unpublished data). This suggests that these seven viruses might be transmitted readily by Asia II 1, at least for viruses frequently found in diseased cotton plants, such as CLCuKoV-Bur and ToLCNDV, considering the fact that Asia II 1 was found to be most abundant in Pakistan where serious cotton leaf curl disease occurred (Ahmed et al. 2011; Ashfaq et al. 2014; Masood et al. 2017). So, it is highly likely that Asia II 1 might be one of the major vectors responsible for the spread and epidemic of these viruses in the field. More investigation concerning the whitefly transmission of these viruses was warranted to test this hypothesis. The other four viruses associated with cotton leaf curl disease, i.e., ACMV, CqCDV, CLCuGeV, and OELCuV, were only identified across a limited area and in a few plants, suggesting a transitory infection (Hameed et al. 2014; Manzoor et al. 2014; Nawaz-ul-Rehman et al. 2012; Tahir et al. 2011).

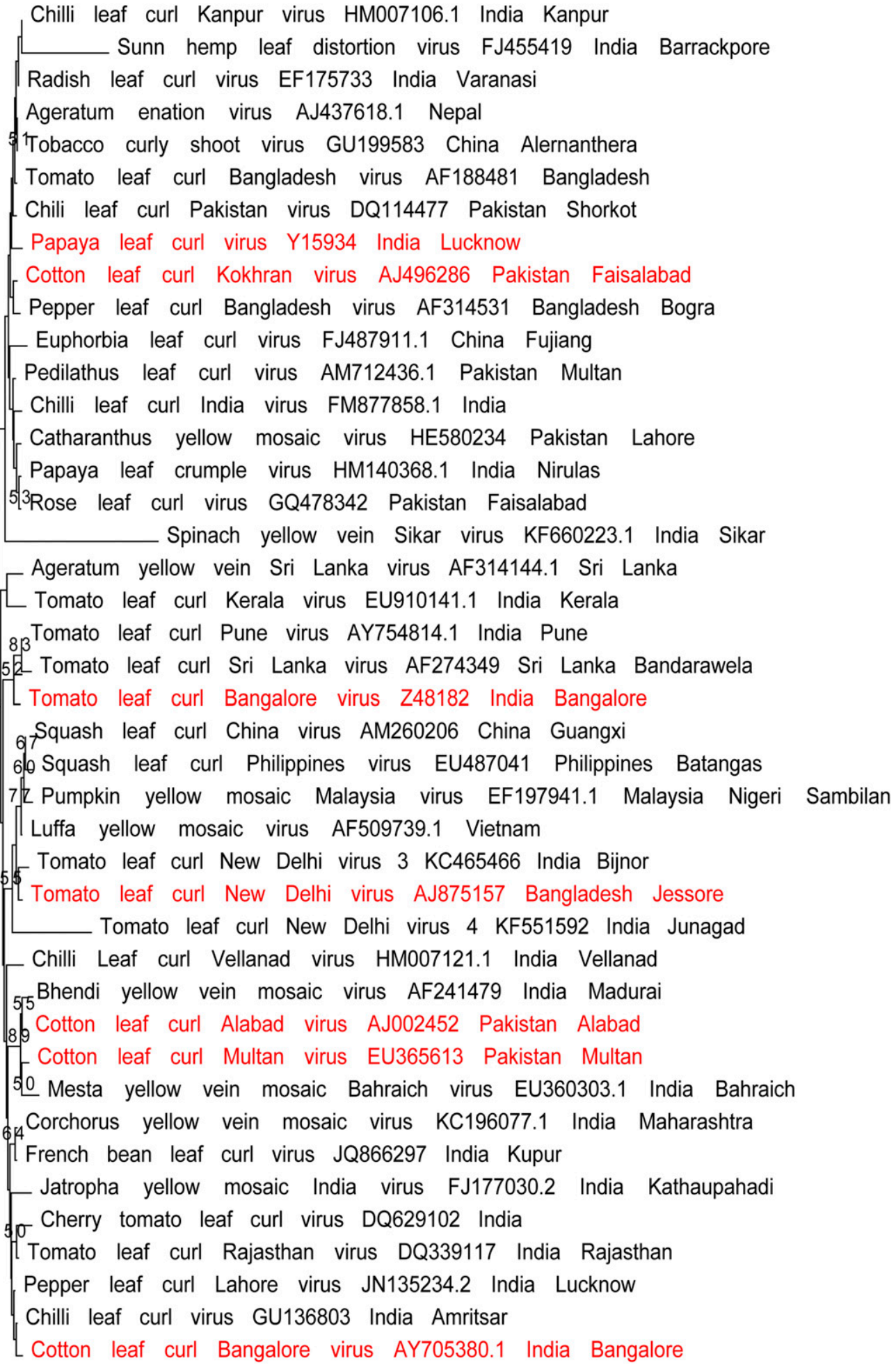

Fig. 8. Enlarged view of the branch where cotton leaf curl Multan virus (CLCuMuV) is located following a phylogenetic analysis. The analysis was conducted with MEGA5 using the neighbor-joining algorithm. All cotton leaf curl disease-associated begomoviruses in this branch, i.e., CLCuMuV, CLCuAlV, CLCuBaV, $\mathrm{CLCuKoV}, \mathrm{PaLCuV}, \mathrm{ToLCNDV}$, and ToLCBaV are indicated by a lighter gray. For phylogenetic analysis, reliability of the phylogenetic relatedness of the branches was evaluated by percentages obtained through 1,000 bootstrap iterations of the datasets and the bootstrap values are shown in the cladogram. 
For these viruses, if they truly share similar whitefly transmission characteristics with CLCuMuV, which can only be transmitted with high efficiency by Asia II 1, then the spread of these viruses to other countries might not cause large epidemics of cotton leaf curl disease since the distribution and abundance of the major vector, Asia II 1 is limited. For example, in China Asia II 1 only occurs in several provinces in the south (Hu et al. 2011). However, recent study has shown that recombination occurred frequently among begomoviruses associated with cotton leaf curl disease during mixed infections (Saleem et al. 2016). Thus, if these viruses spread to other regions where begomoviruses with other efficient vectors, such as TYLCV, are prevalent, then new viruses that can be transmitted efficiently by invasive whitefly species might arise when mixed infections occur (Saleem et al. 2016; Wei et al. 2014). Besides, a mutation of a few amino acids in the coat protein of a begomovirus may significantly alter its whitefly transmission characteristics, so more investigations are needed to evaluate the potential threat of these viruses (Höhnle et al. 2001).

The reason of the differential virus transmission capacity might be due to the differential period of association, i.e., the long-term association provides an opportunity for the virus and vectors to coevolve to the best compatibility, in our case the highest transmission efficiency. The divergence of the species Asia II 1 from the other members in Asia II clades was estimated to occur 18 to 38 million years ago, while the worldwide spread of MEAM1 and MED from their Middle East-Asia Minor and Mediterranean origin occurred in most regions of Asia in a relatively short period (30 to 40 years) (Boykin et al. 2013; De Barro et al. 2011). Although it is difficult to estimate the time when CLCuMuV first came into being, it seems certain that Asia II 1 has been associated with this virus for much longer time than MEAM1 and MED have. Another two studies add weight to this hypothesis. In a study conducted in China with an isolate of TYLCV (a begomovirus that originated from the Middle East) and whitefly populations collected from that country, MEAM1 and MED transmitted TYLCV with almost equal efficiency, while Asia II 1 transmitted the same virus with about half the efficiency of the other two whitefly species (Li et al. 2010). Also, the New World species (formerly biotype A, a B. tabaci species found in the Americas) was found to transmit Chino del tomato virus (a New World bipartite begomovirus) at about twice the efficiency of a MEAM1 population (Idris et al. 2001). It will be interesting and useful to further validate this hypothesis as it can help to assess the whitefly transmission characteristics of a given begomovirus.

To sum up, in the present study, we showed that the efficiency of CLCuMuV transmission by four species of whitefly differed considerably and this differential transmission was associated with the varying efficiency of CLCuMuV to cross the midgut of different whitefly species. Further, the whitefly transmission characteristics of most begomoviruses associated with cotton leaf curl disease were inferred based on a phylogenetic analysis of their coat proteins. Our results highlight the role of Asia II 1 whitefly in the epidemiology of cotton leaf curl disease and provide information for further research regarding whitefly transmission of begomoviruses associated with cotton leaf curl disease.

\section{ACKNOWLEDGMENTS}

We thank M. Zalucki, the University of Queensland, Australia for his help in preparing the manuscript.

\section{LITERATURE CITED}

Ahmed, M. Z., De Barro, P. J., Greeff, J. M., Ren, S. X., Naveed, M., and Qiu, B. L. 2011. Genetic identity of the Bemisia tabaci, species complex and association with high cotton leaf curl disease (CLCuD) incidence in Pakistan. Pest Manag. Sci. 67:307-317.

Akhtar, K. P., Jamil, F. F., Haq, M. A., and Khan, I. A. 2008. Comparison of resistance to cotton leaf curl disease (Multan/Burewala) in Gossypium hirsutum L. varieties and breeding lines. J. Phytopathol. 156:352-357.
Ashfaq, M., Hebert, P. D. N., Mirza, M. S., Khan, A. M., Mansoor, S., Shah, G. S., and Zafar, Y. 2014. DNA barcoding of Bemisia tabaci complex (Hemiptera: Aleyrodidae) reveals southerly expansion of the dominant whitefly species on cotton in Pakistan. PLoS One 9:e104485.

Boykin, L. M., Bell, C. D., Evans, G., Small, I., and De Barro, P. J. 2013. Is agriculture driving the diversification of the Bemisia tabaci species complex (Hemiptera: Sternorrhyncha: Aleyrodidae)?: Dating, diversification and biogeographic evidence revealed. BMC Evol. Biol. 13:228.

Briddon, R. W. 2003. Cotton leaf curl disease, a multicomponent begomovirus complex. Mol. Plant Pathol. 4:427-434.

Briddon, R. W., Akbar, F., Iqbal, Z., Amrao, L., Amin, I., Saeed, M., and Mansoor, S. 2014. Effects of genetic changes to the begomovirus/ betasatellite complex causing cotton leaf curl disease in South Asia post-resistance breaking. Virus Res. 186:114-119.

Briddon, R. W., Mansoor, S., Bedford, I. D., Pinner, M. S., Saunders, K., Stanley, J., Zafar, Y., Malik, K. A., and Markham, P. G. 2001. Identification of DNA components required for induction of cotton leaf curl disease. Virology 285:234-243.

Brown, J. K., Zerbini, F. M., Navas-Castillo, J., Moriones, E., Ramos-Sobrinho, R., Silva, J. C. F., Fiallo-Olive, E., Briddon, R. W., Herna'ndez-Zepeda, C., Idris, A., Malathi, V. G., Martin, D. P., Rivera-Bustamante, R., Ueda, S., and Varsani, A. 2015. Revision of Begomovirus taxonomy based on pairwise sequence comparisons. Arch. Virol. 160:1593-1619.

Cai, J. H., Xie, K., Lin, L., Qin, B. X., Chen, B. S., Meng, J. R., and Liu, Y. L. 2010. Cotton leaf curl Multan virus, newly reported to be associated with cotton leaf curl disease in China. Plant Pathol. 59:794-795.

Chen, T., Tang, Y. F., Zhao, R., He, Z. F., and Lü, L. H. 2016. Identification of the cryptic species of Bemisia tabaci transmitting Cotton leaf curl Multan virus. (in Chinese with English abstract) J. Plant Prot. 43:91-98.

Cui, X. F., Tao, X. R., Xie, Y., Fauquet, C. M., and Zhou, X. P. 2004. A DNA beta associated with Tomato yellow leaf curl China virus is required for symptom induction. J. Virol. 78:13966-13974.

Czosnek, H., Ghanim, M., and Ghanim, M. 2002. The circulative pathway of begomoviruses in the whitefly vector Bemisia tabaci-Insights from studies with Tomato yellow leaf curl virus. Ann. Appl. Biol. 140:215-231.

Datta, S., Budhauliya, R., Das, B., Gopalakrishnan, R., Sharma, S., Chatterjee, S., Vanlalhmuaka, Raju, P. S., and Veer, V. 2017. Rebound of Cotton leaf curl Multan virus and its exclusive detection in cotton leaf curl disease outbreak, Punjab (India), 2015. Sci. Rep. 7:17361.

De Barro, P. J., Liu, S. S., Boykin, L. M., and Dinsdale, A. B. 2011. Bemisia tabaci: A statement of species status. Annu. Rev. Entomol. 56:1-19.

Farooq, A., Farooq, J., Mahmood, A., Shakeel, A., Rehman, A., Batool, A., Riaz, M., Shahid, M., and Mehboob, S. 2011. An overview of cotton leaf curl virus disease (CLCuD) a serious threat to cotton productivity. Aust. J. Crop Sci. 5:1823-1831.

Ghanim, M., Morin, S., and Czosnek, H. 2001. Rate of Tomato yellow leaf curl virus translocation in the circulative transmission pathway of its vector, the whitefly Bemisia tabaci. Phytopathology 91:188-196.

Gu, Z. H., Hu, G. J., Xie, Y., and Zhou, X. P. 2015. Construction and pathogenicity evaluation of infectious clones of Cotton leaf curl Multan virus infecting Hibiscus rosa-sinensis and Gossypium hirtusum. (in Chinese with English abstract) Acta Phytopathol. Sin. 45:198-204.

Gupta, V. K., Sharma, R., Singh, S., Jindal, J., and Dilawari, V. K. 2010. Efficiency of Bemisia tabaci (Gennadius) populations from different planthosts for acquisition and transmission of cotton leaf curl virus. Indian J. Biotechnol. 9:271-275.

Hameed, U., Ziaurrehman, M., Herrmann, H. W., Haider, M. S., and Brown, J. K. 2014. First report of Okra enation leaf curl virus and associated cotton leaf curl Multan betasatellite and cotton leaf curl multan alphasatellite infecting cotton in Pakistan: A new member of the cotton leaf curl disease complex. Plant Dis. 98:1447.

Höhnle, M., Höfer, P., Bedford, I. D., Briddon, R. W., Markham, P. G., and Frischmuth, T. 2001. Exchange of three amino acids in the coat protein results in efficient whitefly transmission of a nontransmissible Abutilon mosaic virus isolate. Virology 290:164-171.

Hu, J., De Barro, P. J., Zhao, H., Wang, J., Nardi, F., and Liu, S. S. 2011. An extensive field survey combined with a phylogenetic analysis reveals rapid and widespread invasion of two alien whiteflies in China. PLoS One 6: e16061.

Idris, A. M., Smith, S. E., and Brown, J. K. 2001. Ingestion, transmission, and persistence of chino del tomate virus (CdTV), a new world begomovirus, by old and new world biotypes of the whitefly vector Bemisia tabaci. Ann. Appl. Biol. 139:145-154.

Kirthi, N., Priyadarshini, C. G., Sharma, P., Maiya, S. P., Hemalatha, V., Sivaraman, P., Dhawan, P., Rishi, N., and Savithri, H. S. 2004. Genetic variability of begomoviruses associated with cotton leaf curl disease originating from India. Arch. Virol. 149:2047-2057.

Lefeuvre, P., Martin, D. P., Harkins, G., Lemey, P., Gray, A. J., Meredith, S., Lakay, F., Monjane, A., Lett, J., Varsani, A., and Heydarnejad, J. 2010. The 
spread of Tomato yellow leaf curl virus from the Middle East to the world. PLoS Pathog 6:e1001164.

Li, M., Hu, J., Xu, F. C., and Liu, S. S. 2010. Transmission of Tomato yellow leaf curl virus by two invasive biotypes and a Chinese indigenous biotype of the whitefly Bemisia tabaci. Int. J. Pest Manage. 56:275-280.

Mansoor, S., Amin, I., Iram, S., Hussain, M., Zafar, Y., Malik, K. A., and Briddon, R. W. 2003. Breakdown of resistance in cotton to cotton leaf curl disease in Pakistan. Plant Pathol. 52:784.

Manzoor, M. T., Ilyas, M., Shafiq, M., Haider, M. S., Shahid, A. A., and Briddon, R. W. 2014. A distinct strain of Chickpea chlorotic dwarf virus (genus Mastrevirus, family Geminiviridae) identified in cotton plants affected by leaf curl disease. Arch. Virol. 159:1217-1221.

Mao, M. J., He, Z. F., Yu, H., and Li, H. P. 2008. Molecular characterization of Cotton leaf curl Multan virus and its satellite DNA that infects Hibiscus rosa-sinensis. Chin. J. Virol. 24:64-68 (in Chinese with English abstract).

Masood, M., Amin, I., Hassan, I., Mansoor, S., Brown, J. K., and Briddon, R. W. 2017. Diversity and distribution of cryptic species of the Bemisia tabaci (Hemiptera: Aleyrodidae) complex in Pakistan. J. Econ. Entomol. 110:2295-2300.

Navas-Castillo, J., Fiallo-Olivé, E., and Sánchez-Campos, S. 2011. Emerging virus diseases transmitted by whiteflies. Annu. Rev. Phytopathol. 49: 219-248.

Nawaz-ul-Rehman, M. S., Briddon, R. W., and Fauquet, C. M. 2012. A melting pot of old world begomoviruses and their satellites infecting a collection of Gossypium species in Pakistan. PLoS One 7:e40050.

Pan, L. L., Chen, Q. F., Zhao, J. J., Guo, T., Wang, X. W., Hariton-Shalev, A., Czosnek, H., and Liu, S. S. 2017. Clathrin-mediated endocytosis is involved in Tomato yellow leaf curl virus transport across the midgut barrier of its whitefly vector. Virology 502:152-159.

Qin, L., Wang, J., Bing, X. L., and Liu, S. S. 2013. Identification of nine cryptic species of Bemisia tabaci (Hemiptera: Aleyrodidae) from China by using the mtCOI PCR-RFLP technique. Acta Entomol Sin. 56:186-194 (in Chinese with English abstract).

Rosen, R., Kanakala, S., Kliot, A., Cathrin, P. B., Farich, B. A., Santanamagal, N., Elimelech, M., Kontsedalov, S., Lebedev, G., Cilia, M., and Ghanim, M. 2015. Persistent, circulative transmission of begomoviruses by whitefly vectors. Curr. Opin. Virol. 15:1-8.

Ruan, Y. M., Luan, J. B., Zang, L. S., and Liu, S. S. 2007. Observing and recording copulation events of whiteflies on plants using a video camera. Entomol. Exp. Appl. 124:229-233.

Saleem, H., Nahid, N., Shakir, S., Ijaz, S., Murtaza, G., Khan, A. A., Mubin, M., and Nawaz-ul-Rehman, M. S. 2016. Diversity, mutation and recombination analysis of cotton leaf curl geminiviruses. PLoS One 11: $\mathrm{e} 0151161$

Sattar, M. N., Kvarnheden, A., Saeed, M., and Briddon, R. W. 2013. Cotton leaf curl disease-An emerging threat to cotton production worldwide. J. Gen. Virol. 94:695-710.

Simón, B., Cenis, J. L., Beitia, F., Khalid, S., Moreno, I. M., Fraile, A., and García-Arenal, F. 2003. Genetic structure of field populations of begomoviruses and of their vector Bemisia tabaci in Pakistan. Phytopathology 93: $1422-1429$.

Sinisterra, X. H., McKenzie, C. L., Hunter, W. B., Powell, C. A., and Shatters, R. G. 2005. Differential transcriptional activity of plant pathogenic begomoviruses in their whitefly vector (Bemisia tabaci, Gennadius: Hemiptera Aleyrodidae). J. Gen. Virol. 86:1525-1532.

Tahir, M. N., Amin, I., Briddon, R. W., and Mansoor, S. 2011. The merging of two dynasties-Identification of an African cotton leaf curl diseaseassociated begomovirus with cotton in Pakistan. PLoS One 6:e20366.

Tamura, K., Peterson, D., Peterson, N., Stecher, G., Nei, M., and Kumar, S. 2011. MEGA5: Molecular evolutionary genetics analysis using maximum Likelihood, evolutionary distance, and maximum parsimony methods. Mol. Biol. Evol. 28:2731-2739.

Wei, J., Zhao, J. J., Zhang, T., Li, F. F., Ghanim, M., Zhou, X. P., Ye, G. Y., Liu, S. S., and Wang, X. W. 2014. Specific cells in the primary salivary glands of the whitefly Bemisia tabaci control retention and transmission of begomoviruses. J. Virol. 88:13460-13468.

Xia, W. Q., Liang, Y., Chi, Y., Pan, L. L., Zhao, J., Liu, S. S., and Wang, X. W. 2018. Intracellular trafficking of begomoviruses in the midgut cells of their insect vector. PLoS Pathog 14:e1006866.

Zaidi, S. E. A., Shafiq, M., Amin, I., Scheffler, B. E., Scheffler, J. A., Briddon, R. W., and Mansoor, S. 2016. Frequent occurrence of Tomato leaf curl New Delhi virus in cotton leaf curl disease affected cotton in Pakistan. PLoS One 11:e0155520.

Zhang, H., Gong, H. R., and Zhou, X. P. 2009. Molecular characterization and pathogenicity of Tomato yellow leaf curl virus in China. Virus Genes 39: 249-255.

Zhou, X. P., Liu, Y., Robinson, D. J., and Harrison, B. D. 1998. Four DNA-A variants among Pakistani isolates of Cotton leaf curl virus and their affinities to DNA-A of geminivirus isolates from okra. J. Gen. Virol. 79: 915-923.

Zubair, M., Zaidi, S., Shakir, S., Farooq, M., Amin, I., Scheffler, J. A., Scheffler, B. E., and Mansoor, S. 2017. Multiple begomoviruses found associated with cotton leaf curl disease in Pakistan in early 1990 are back in cultivated cotton. Sci. Rep. 7:680. 